\title{
Membandingkan Status Hematologis Pasien Malaria Falciparum dengan Vivax di RSUP M. Djamil Januari 2011 - Maret 2013
}

\author{
Miftahul Jannah Afdhal ${ }^{1}$, Nurhayati ${ }^{2}$, Julizar $^{3}$
}

\begin{abstract}
Abstrak
Malaria merupakan masalah kesehatan yang besar di daerah tropis dan subtropis termasuk di Indonesia. Jenis malaria yang sering terjadi di daerah Sumatera adalah malaria falciparum dan vivax. Penelitian ini bertujuan untuk mengetahui perbedaan status hematologis pasien malaria falciparum dengan malaria vivax. Jenis penelitian ini adalah analitik retrospektif, dengan jumlah sampel sebanyak 67 orang. Data dikumpulkan melalui hasil rekam medis yang kemudian dianalisis melalui uji T-test Independent dan Mann-Whitney. Hasil penelitian ini didapatkan nilai signifikasi $p<0,05$ pada perbedaan nilai hemoglobin yaitu 0,027 , perbedaan nilai hematokrit yaitu 0,03 , dan pada perbedaan jumlah trombosit yaitu 0,03 . Nilai signifikasi $p>0,05$ pada jumlah hitung leukosit yaitu 0,89 .Dari hasil penelitian ini dapat disimpulkan bahwa terdapat nilai hemoglobin, hematokrit dan trombosit pada pasien malaria falciparum signifikan lebih rendah daripada malaria vivax. Jumlah leukosit pada pasien malaria falciparum tidak signifikan lebih rendah daripada malaria vivax.
\end{abstract}

Kata kunci : malaria falciparum, malaria vivax, hematologis

\begin{abstract}
Malaria is a major public health problem in tropical and subtropical country, including in Indonesia. The most type of malaria in Sumatera are malaria falciparum and vivax. The objective of this study was to determine haematological status in falciparum and vivax malaria patient at M Djamil hospital. This study was an analytic retrospective study, with a total sample of 67 patients. Data were collected through medical records than analyzed by T-test Independent and Mann-Whitney. The result of this study, the significance value $p<0,05$ were found in difference of hemoglobin value $(0,027)$, in difference of haematocrit value $(0,03)$ and in difference of thrombocyte count $(0,03)$. The significance value $p>0,05$ was found in difference of leukocyte count $(0,89)$. From these result, it can be concluded that the haemoglobin value, haematocrit value and thrombocyte count are significantly lower in falciparum malaria patient than vivax malaria patient. Leukocyte count is not significantly lower in falciparum malaria patient than vivax malaria patient.
\end{abstract}

Keywords: falciparum malaria, vivax malaria, haematological

Affiliasi penulis : 1. Pendidikan Dokter FK UNAND (Fakultas Kedokteran Universitas Andalas Padang), 2. Bagian Parasitologi FK UNAND, 3. Bagian Fisika FK UNAND

Korespondensi : MiftahulJannahAfdhal, email : adek_odneill@yahoo.com, Telp: 085263120299

\section{PENDAHULUAN}

Malaria adalah penyakit infeksi oleh parasit Plasmodium yang ditularkan ke manusia melalui gigitan nyamuk Anopheles betina yang terinfeksi. Asia
Tenggara dilaporkan menjadi wilayah kedua terbesar yang terinfeksi malaria di dunia. ${ }^{1} \mathrm{Di}$ Asia Tenggara terdapat tiga negara yang mendominasi kasus malaria, yaitu India dengan 24 juta kasus per tahun, disusul Indonesia dan Myanmar. ${ }^{2}$ Di Kota Padang jumlah penderita malaria mengalami peningkatan kasus yang sangat signifikan, yaitu dari 187 kasus pada tahun 2010 menjadi 340 kasus pada tahun $2011 .^{3}$ Berdasarkan data instalasi bagian rawat inap 
IImu Penyakit Dalam RSUP Dr. M. Djamil Padang yang merupakan rumah sakit rujukan pemerintah untuk wilayah Sumatera Bagian Tengah, jumlah pasien malaria dari Januari 2012 hingga Maret 2013 mencapai 125 kasus dengan 9 orang dinyatakan meninggal. Pada pasien malaria terjadi perubahan status hematologis meliputi anemia (penurunan kadar hemoglobin), trombositopenia dan leukopenia hingga leukositosis karena proses hemolisis oleh parasit malaria. Perubahan status hematologis tersebut sering dilaporkan menyebabkan komplikasi yang berarti. ${ }^{4}$ Penelitian di Uttarakhand, India, menemukan bahwa komplikasi yang disebabkan oleh malaria dapat dihindari dengan pengontrolan status hematologis pasien malaria dan penatalaksanaan dini. ${ }^{5}$ Menurut penelitian di Institusi Oswaldo Cruz dan Institusi Kothari, menemukan tidak terdapat perbedaan status hematologis pada penderita malaria. ${ }^{6}$ Berdasarkan uraian data di atas, penelitian ini bertujuan untuk mengetahui apakah terdapat perbedaan aspek hematologis pada pasien malaria falciparum dan malaria vivax di RSUP M. Djamil Padang pada Januari 2011 hingga Maret 2013.

\section{METODE}

Jenis Penelitian ini adalah analtik observasional dengan desain retrospective. Populasi penelitian adalah seluruh pasien dengan diagnosis malaria yang dirawat di bagian IImu Penyakit Dalam RSUP Dr. M. Djamil Padang yang terdapat dalam rekam medik dari 1 Januari 2011 sampai 31 Maret 2013. Sampel berjumlah 67 orang yang diambil dengan metode total sampling. Kriteria inklusi adalah mempunyai catatan medik (status) yang lengkap sesuai dengan data yang dibutuhkan dalam penelitian (Identitas lengkap meliputi nama, umur dan jenis kelamin, Jenis malaria berdasarkan spesies, Nilai hemoglobin, Nilai hematokrit, Jumlah trombosit, Jumlah leukosit). Variabel dependen adalah Plasmodium falciparum dan Plasmodium vivax, sedangkan variable independent adalah status hematologist yang dilihat dari rekam medik. Langkahlangkah pengolahan data adalah pemeriksaan kelengkapan dan kejelasan data, pemberian kode pada setiap data variabel, memasukkan data dalam program SPSS (Statistical Program for Social Science), serta pemeriksaan kembali untuk memastikan bahwa data tersebut telah bersih dari kesalahan. Analisis data terdiri dari analisis univariat dan bivariat. Pada analisis bivariat dilakukan dengan menggunakan uji beda dua mean independen (uji $t$ independen) dengan batas kemaknaan $P>0,05$ jika distribusi data normal. Jika distribusi data tidak normal dilakukan uji non-parametrik seperti uji Mann-Whitney.

\section{HASIL}

\section{Karakteristik Responden}

Tabel 1. Karakteristik Responden

\begin{tabular}{lcc}
\hline \multicolumn{1}{c}{ Karakteristik } & $\mathbf{n}$ & $\%$ \\
\hline JenisKelamin & 25 & 37.3 \\
Laki-laki & 42 & 62.7 \\
Perempuan & & \\
Usia & 9 & 13.4 \\
$<20$ & 30 & 44.8 \\
$20-40$ & 28 & 41.8 \\
$>40$ & & \\
SpesiesPenyebab & 19 & 28.4 \\
$P$. falciparum & 48 & 71.6 \\
$P$. vivax & 0 & 0 \\
$P$. malariae & 0 & 0 \\
$P$. ovale & 0 & 0 \\
$P$. knowlesi & 0 & 0 \\
Mix Infection & & \\
\hline
\end{tabular}

Berdasarkan tabel 1 dapat diketahui bahwa pasien malaria terbanyak adalah perempuan sebanyak 42 orang (62,7\%). Berdasarkan karakteristik umur, diketahui bahwa pasien malaria terbanyak berada pada kelompok usia 20 - 40 tahun sebanyak 30 orang $(44,8 \%)$. Spesies terbanyak yang menyebabkan kasus malaria adalah $P$. vivax sebesar $71,6 \%$ dan diikuti oleh P.falciparum sebesar $28,4 \%$. Sementara untuk $P$. malariae, $P$. ovale dan $P$. Knowles / tidak ada ditemukan.

Tabel 2 memperlihatkan nilai rata-rata hemoglobin, hematokrit dan trombosit pada pasien malaria falciparum lebih rendah daripada malaria vivax. Kadar leukosit pada malaria falciparum lebih tinggi daripada malaria vivax. 


\section{Hasil Analisis Univariat}

Tabel 2. Karakteristik Status Hematologis Pasien Malaria Falciparum danVivax

\begin{tabular}{|c|c|c|c|}
\hline \multicolumn{2}{|c|}{ Status Hematologis } & \multirow{3}{*}{$\begin{array}{c}\begin{array}{c}\text { Malaria } \\
\text { Falciparum } \\
(\mathbf{n}=19)\end{array} \\
11,26 \pm 2,16\end{array}$} & \multirow{3}{*}{$\begin{array}{c}\begin{array}{c}\text { Malaria } \\
\text { Vivax } \\
(\mathbf{n}=\mathbf{4 8})\end{array} \\
12,5 \pm 2,06\end{array}$} \\
\hline Nilai Hemoglobin & Rata - rata & & \\
\hline & $\pm s . b$ & & \\
\hline & NilaiRange & $8,20-15,00$ & $6,10-17,40$ \\
\hline \multirow[t]{2}{*}{ Nilai Hematokrit } & $\begin{array}{l}\text { Rata - rata } \\
\pm \text { s.b }\end{array}$ & $34,00 \pm 7,82$ & $38,55 \pm 7,48$ \\
\hline & NilaiRange & $15,07-46,00$ & $\begin{array}{c}17,30- \\
63,00\end{array}$ \\
\hline \multirow[t]{4}{*}{ Jumlah Leukosit } & Rata - rata & $8.777 \pm 6.570$ & $7.772 \pm$ \\
\hline & $\pm s . b$ & & 3.714 \\
\hline & NilaiRange & $2.880-29.000$ & $3.100-$ \\
\hline & & & 20.400 \\
\hline \multirow[t]{4}{*}{ JumlahTrombosit } & Rata - rata & $129.584 \pm$ & $192.625 \pm$ \\
\hline & $\pm s . b$ & 102.397 & 119.744 \\
\hline & NilaiRange & $17.600-$ & $24.000-$ \\
\hline & & 354.00 & 540.000 \\
\hline
\end{tabular}

Tabel 3 dibawah ini memperlihatkan hasil uji statistik nilai hemoglobin, hematokrit dan trombosit pada pasien malaria falciparum signifikan lebih rendah daripada malaria vivax $(p<0,05)$. Tidak terdapat perbedaan yang bermakna antara jumlah leukosit ratarata pasien malaria faciparum dan vivax.

\section{Hasil Analisis Bivariat}

Tabel 3. Gambaran Status Hematologis Pasien Malaria Falciparum danVivax

\begin{tabular}{|c|c|c|c|c|}
\hline $\begin{array}{c}\text { Status } \\
\text { Hematologis }\end{array}$ & $\begin{array}{c}\text { Jenis } \\
\text { Malaria }\end{array}$ & Median & $\begin{array}{l}\text { Rata- } \\
\text { rata } \\
\pm s . b\end{array}$ & $p$ \\
\hline $\begin{array}{l}\text { Nilai Hemoglobin } \\
(\mathrm{g} / \mathrm{dl})\end{array}$ & $\begin{array}{l}\text { Malaria } \\
\text { falciparum } \\
\text { Malaria } \\
\text { vivax }\end{array}$ & 12,70 & & 0,03 \\
\hline $\begin{array}{l}\text { NilaiHematokrit } \\
\text { (\%) }\end{array}$ & $\begin{array}{l}\text { Malaria } \\
\text { falciparum } \\
\text { Malaria } \\
\text { vivax }\end{array}$ & & $\begin{array}{c}34,00 \pm \\
7,8 \\
38,6 \pm \\
7,4\end{array}$ & 0,03 \\
\hline $\begin{array}{l}\text { Jumlah leukosit } \\
(/ \mu \mathrm{L})\end{array}$ & $\begin{array}{l}\text { Malaria } \\
\text { falciparum } \\
\text { Malaria } \\
\text { vivax }\end{array}$ & & $\begin{array}{c}8.777 \pm \\
6.568 \\
7.772 \pm \\
3.714\end{array}$ & 0,85 \\
\hline $\begin{array}{l}\text { Jumlah } \\
\text { trombosit (sel/L) }\end{array}$ & $\begin{array}{l}\text { Malaria } \\
\text { falciparum } \\
\text { Malaria } \\
\text { Vivax }\end{array}$ & 177.000 & & 0,03 \\
\hline
\end{tabular}

\section{PEMBAHASAN}

Perbandingan Nilai Hemoglobin dan Hematokrit pada Pasien Malaria Falciparum dan Malaria Vivax

Median nilai hemoglobin dan rata - rata hematokrit pada pasien malaria falciparum lebih rendah secara signifikan dibandingkan pasien malaria vivax. Menurut penelitian Patel (2013) menyatakan bahwa terdapat perbedaan penurunan nilai hemoglobin dan hematokrit yang signifikan antara pasien malaria falciparum dan vivax. ${ }^{7}$

$P$. falciparum dapat memodifikasi permukaan eritrosit sehingga stadium gametosit dan aseksual dapat melekat. Parasit dapat menyebar keseluruh pembuluh kapiler dan membentuk knob. Kemudian terjadi sito adherensi atau perlekatan eritrosit yang terinfeksi dengan eritrosit normal membentuk gerombolan (rosette), akibatnya terjadi pemecahan eritrosit dalam jumlah besar. ${ }^{8}$

Pada malaria falciparum terjadi perlekatan eritrosit yang terinfeksi dengan endotelial vaskular sehingga menyebabkan alterasi toksik malaria yang mengakibatkan umur eritrosit menjadi pendek. ${ }^{9}$ Malaria falciparum memproduksi Th-1 lebih tinggi dari malaria yang lainnya sehingga menimbulkan anemia yang lebih berat. $^{10}$

\section{Perbandingan Nilai Leukosit Pada Pasien Malaria Falciparum dan Malaria Vivax}

Berdasarkan hasil penelitian didapatkan tidak terdapat perbedaan yang signifikan antara jumlah hitung rata - rata leukosit pada pasien malaria falciparum danpasien malaria vivax. Hal ini sesuai dengan penelitian Akhtar yang menyatakan bahwa $86 \%$ pasien malaria memiliki jumlah hitung leukosit pada kisaran normal, sehingga perbandingan jumlah hitung leukosit pada kedua kelompok menjadi tidak bermakna. ${ }^{4}$

Leukositosis dapat terjadi pada keadaan anemia hemolitik yang berat karena adanya stimulasi hematopoesis secara keseluruhan akibat anemia tersebut dan peningkatan dari sel proinflamasi. ${ }^{9}$ Pada penelitian ini, rata - rata anemia yang terjadi pada pasien malaria masih termasuk kategori anemia ringan 
sehingga kemungkinan terjadinya perubahan jumlah hitung leukosit hanya sedikit.

\section{Perbandingan Nilai Trombosit Pada Pasien Malaria Falciparum dan Malaria Vivax}

Nilai median trombosit pada pasien malaria falciparum lebih rendah signifikan dibandingkan pasien malaria vivax. Hal ini sesuai dengan penelitian Patel, penurunan nilai trombosit rata - rata pada pasien malaria falciparum lebih rendah signifikan dibandingkan pasien malaria vivax. ${ }^{7}$

Hal ini sesuai dengan kepustakaan, bahwa eritrosit yang terinfeksi $P$. falciparum memiliki sifat mudah melekat. Eritrosit cenderung melekat pada eritrosit lainnya yang tidak terinfeksi, trombosit dan endotel kapiler. Perlengketan eritrosit dengan trombosit dapat mengakibatkan trombositopenia. ${ }^{8}$

Proses lisisnya eritrosit juga memicu immunomodulator multipoten CD40L dan reseptornya yaitu CD40 dalam penghancuran platelet dan pembentukan mikropartikel platelet. Pembentukan mikropartikel platelet mengakibatkan penurunan yang signifikan dari IFN-y dan IL-2 dan peningkatan IL-10 sehingga terjadi gangguan dalam respon imun sel mediator. Perubahan sel mediator menyebabkan munculan klinis berupa trombositopenia. ${ }^{11}$

\section{KESIMPULAN}

1. Sebagian besar kejadian malaria di RSUP Dr. M. Djamil adalah malaria vivax.

2. Kejadian anemia, leukopenia, leukositosis dan trombositopenia lebih banyak terjadi pada malaria falciparum.

3. Terdapat perbedaan bermakna antara nilai median hemoglobin falciparum dan vivax. Nilai median hemoglobin pada malaria falciparum lebih rendah daripada malaria vivax.

4. Terdapat perbedaan bermakna antara nilai median hematokrit falciparum dan vivax. Nilai median hematokrit pada malaria falciparum lebih rendah daripada malaria vivax.

5. Tidak terdapat perbedaan bermakna antara jumlahleukosit rata-rata malaria falciparum dan vivax.

6. Terdapat perbedaan bermakna antara jumlah trombosit median malaria falciparum dan vivax.
Nilai median trombosit pada malaria falciparum lebih rendah daripada malaria vivax.

\section{DAFTAR PUSTAKA}

1. Baldy CM. Gangguan sel darah merah. Dalam: Price SA, Lorraine MW, editor (penyunting). Patofisiologi Konsep Klinik Proses-Proses Penyakit (terjemahan).Jakarta:EGC;2006.hlm. 25.

2. WHO. Disease burden in world malaria report fact sheet 2012. Switzerland; 2012.

3. Dinas Kesehatan Kota Padang. laporan tahunan dinas kesehatan kota Padang tahun 2012 (diunduh 17 Februari 2013). Tersedia dari: URL: HYPERLINK: www.dinkeskotapadang1.files. wordpress.com.

4. Akhtar S, Gumashta R, Mahore R, Maimoon S. hematological changes in malaria: a comparative study. IOSR Journal of Pharmacy and Biological Science. 2012;2(4): 15-9.

5. Chandra $\mathrm{S}$, Chandra $\mathrm{H}$. Role of haematological parameters as an indicator of acute malarial infection in Uttarakhand State of India. Mediterran Journal Hematological Infection Disease. 2013;5(1): 1-2.

6. Kochar DK, Tanwar GS, Khatri PC. Clinical features of children hospitalized with malaria in Bikaner, Nortwest India. The American Society Journal of Tropical Medicine and Hygiene. 2010; 83(5): 981-9.

7. Patel A, Jain S, Patel B, Modi B,. Hematological changes in plasmodium falciparum and plasmodium vivax malaria. National Journal of Medical Research.2013;3(2):130-3.

8. Sutanto I, Pribadi W, Parasit malaria. Dalam: Sutanto I, Ismid IS, Sjarifudin PK, Sungkar S, editor (penyunting). Buku Ajar Parasitologi Kedokteran. Jakarta: Balai Penerbit FKUI; 2008. hlm. 189-20.

9. Munker R. Anemias. In: Munker R, Hiller E, Glass J, Paquette R, editor (penyunting). Modern Hematology. New Jersey: Humana Press; 2007. hlm.90.

10. Baratawidjaja KG, Rengganis I. Imunologi infeksi. Dalam: Imunologi dasar. Jakarta: Balai Penerbit FKUI;2009. hIm. 441-4.

11. Greer JP, Foerster J, Rodgers GM, Paraskevas F, Glader B, Arber DA. miscellaneous causes of 
thrombocytopenia. In Wintrobe's clinical

hlm. 1331-2.

Hematology. Philadelpia: Wolter Klower; 2012. 